EPiC Series in Language and Linguistics
Volume 2, 2017, Pages 119-126
Professional and Academic Discourse:
an Interdisciplinary Perspective

\title{
The Role of Visual Metaphor in Visual Genres
}

\author{
Isabel Negro \\ Universidad Complutense de Madrid, Spain. \\ inegro@ccee.ucm.es
}

\begin{abstract}
In the last decades metaphor has been a paramount research topic within the Cognitive Metaphor Theory. Although initially linguistic metaphor received most attention, in recent years the research focus has shifted from verbal metaphor to other types of monomodal and multimodal metaphor (Forceville 2009). One research line has been the study of visual metaphor, i.e. metaphor instantiated through image, in specialised language, including political cartooning (e.g. El Refaie 2003), winespeak (e.g. Caballero 2009) and advertising (Forceville 2008). In the present article I examine the evaluative role of visual metaphor in two visual genres - advertising and political cartooning - through a corpus of English, French and Spanish ads and cartoons. It will be argued that while in advertising metaphor enhances the product qualities or presents it as a necessity, thus working as a persuasive tool, in cartooning metaphor shows the author's critical stance towards a news event.
\end{abstract}

\section{Introduction}

In the last decades metaphor has been vastly researched within the Cognitive Metaphor Theory developed by Lakoff and other scholars (e.g. Lakoff, 1987, 2006; Lakoff \& Johnson, 1980, 1999; cf. Ruiz de Mendoza \& Pérez, 2011 for assessment on the later versions).

The Conceptual Metaphor Theory is based on the following principles (Lakoff, 2006):

- Metaphor is primarily a cognitive mechanism.

- Metaphor involves understanding a domain of experience (the target domain) in terms of a more concrete domain (the source domain).

- A metaphor is to be regarded as a mapping (e.g. a fixed set of conceptual correspondences) between a source domain and a target domain, where one or more features of the source are projected upon the target. As Lakoff (2006: 192) remarks, a metaphor is "an ontological mapping across conceptual domains" so that "the essence of meaning is understanding and experiencing one kind of thing in terms of another” (Lakoff \& Johnson 1980: 5).

- Any linguistic metaphor, or metaphoric expression, is an instantiation of a conceptual metaphor. 
Although initially the emphasis was laid on verbal metaphor, other types of monomodal metaphor such as visual metaphor, i.e. metaphor instantiated through image, have received much attention, particularly in specialised language. Thus metaphor is a recurrent device used in advertising (Forceville, 2008; Velasco \& Fuertes 2006; Negro 2013a) and political cartooning (El Refaie, 2003; Shilperoord \& Maes 2009; Negro 2013b, 2014). The aim of the present paper is to examine the evaluative role of visual metaphor in these genres. The functions of metaphor have been widely researched, particularly in politics (e.g. Charteris-Black 2005; Musolff \& Zinken 2009; Negro 2015) and business (e.g. Skorczynska \& Deignan, 2006; Silaški \& Durović, 2010). Researchers have discussed the cognitive, persuasive and evaluative functions of verbal metaphor in those contexts. Firstly, metaphor is a means of conceptualizing and expressing issues in political and business discourse. In line with this, metaphor frames thinking. Secondly, metaphorical choices convey the author's evaluation of policies or political rivals in political discourse and of economic phenomena in business discourse. As far as visual genres are concerned, metaphor works as an evaluative device in advertising and political cartooning. On the one hand, metaphor in advertising conveys a positive evaluation of the product being advertised. Such evaluative function is based on the rhetorical role of metaphor as a persuasive technique. On the other hand, visual metaphor in political cartooning yields a negative evaluation of a political issue, thus highlighting the critical position of the cartoonist about the topic.

\section{Sample Analysis}

In order to show the evaluative role of visual metaphor, I have gathered a small sample of ads and cartoons. The ads have been drawn from the website adsoftheworld.com and the magazine MarieClaire, while the cartoons have been drawn by El Roto for the Spanish newspaper El País.

\subsection{Analysis of the Ads}

In the first set of ads metaphor serves to enhance the product features. Thus the ad shown in figure 1 enhances the value of reading. The image depicts Popeye's bulging arm in the shape of a book, thus containing an intertextuality element. The books instantiate the metonymy INSTRUMENT (i.e. books) FOR ACTION (i.e. reading), which is subsumed within the metaphor BOOKS ARE SPINACH, with a mapping from physical growth to intellectual growth, as suggested by the label on the tin of spinach Para crecer fuerte 'To grow strong' in the bottom left corner. In structural terms, we are confronted with a case of yuxtaposition, since both the source and the target object appear in the ad.

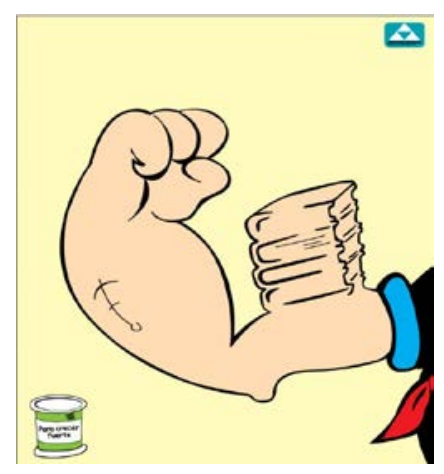

Figure 1: Ad to promote reading (adsoftheworld.com).

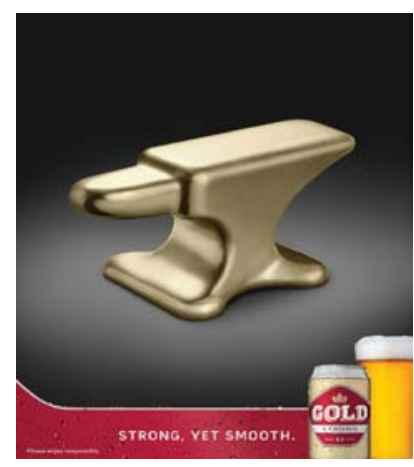

Figure 2: The Gold beer (adsoftheworld.com). 
The ad for the Gold beer (figure 2) highlights its strength and smoothness by forging a conceptual link between the product and an anvil based on these features. It is the text 'Strong, yet smooth' that triggers the mapping from the source to the target.

The ad in figure 3 enhances one particular property of the newspaper Chicago Tribune, i.e. its degree of informativity, through the text Covering the stories you need to know. The stories are metaphorically cued by the image of an open suitcase, which activates the metaphor OPENING A SUITCASE IS REVEALING A STORY. Again the verbal element allows for the correct interpretation of the ad.

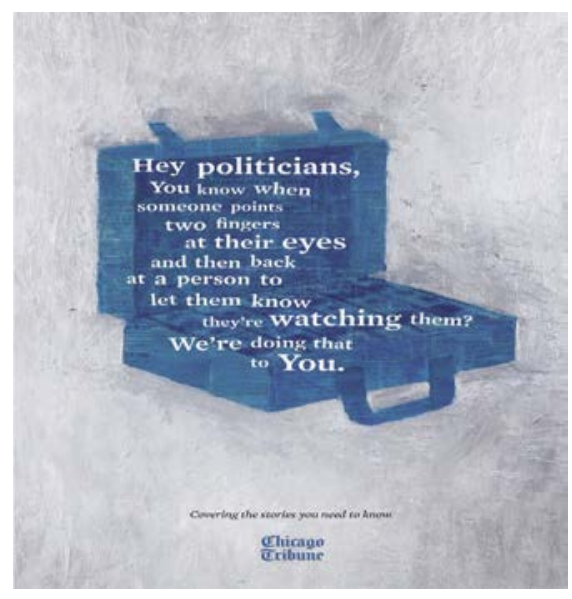

Figure 3: The Chicago Tribune (adsoftheworld.com)

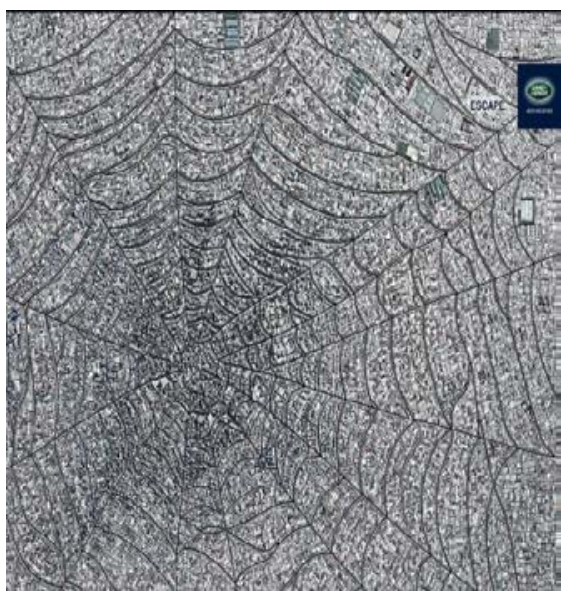

Figure 4: LandRover (adsoftheworld.com)

The metaphor encoded in the next ad (figure 4) enhances the benefits of the product by associating it with social values such as freedom. The city is metaphorically represented as a spiderweb which traps people, who can only escape in a Landrover (the product advertised). The metaphor has a metonymic basis, inasmuch as the source is a city map, which stands for the city.

In the second set of ads metaphor contributes to product promotion by proposing a view of the product as a necessity rather than as a luxury. The ad for Sylphide cheese (figure 5) profiles the reifying metaphor WOMEN ARE MICE, which relies on a part-for-the-whole metonymy, the woman in the picture representing all women. The conceptual similarity between women and mice is based on a common feature: they both love cheese. Metaphor serves to show the cheese as a product that consumers cannot do with, as the copy indicates: On ne demande pas à une souris de se passer de fromage 'A mouse cannot be asked to do without cheese'. The choice of women as the target is determined by the main product feature: it is a light cheese that helps women to be slim, as the brand name Sylphide suggests. On the formal plane, the ad is an instance of substitution. The source object is merely evoked by the image of the hole, although it is verbally rendered by the words piéger 'trap' and souris 'mouse'. 


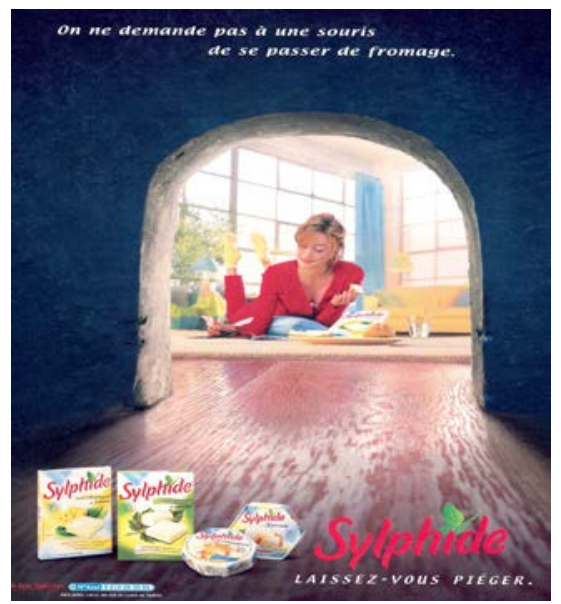

Figure 5: The Sylphide cheese (Marie-Claire, January 2011)

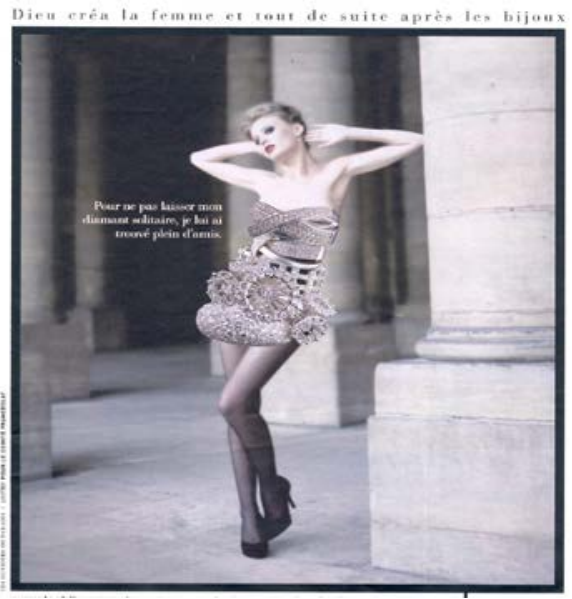

Figure 6: Les Bijoux Précieux. (Marie-Claire, March 2011)

In much the same way, the image shown in figure 6 presents the product advertised, i.e. jewellery, as an indispensable item by equating jewels with clothes. The text highlights the relevance of jewellery: Dieu créa la femme et tout de suite après les bijoux 'God created a woman and then jewellery'. The clause Dieu créa la femme is reminiscent of an intertextuality element since it evokes the title of a famous French film directed by Roger Vadim in 1956 and starring Brigitte Bardot.

The ad for a medicine in figure 7 highlights the product benefits by integrating it within the metaphoric scenario of war, where the central metaphor is DISEASES ARE ENEMIES. This metaphor activates the following mappings:

- $\quad$ People suffering from a cold are soldiers who fight against it.

- Humex reflex is the shield that protects sick people against the cold.

The metaphor is cued by both the image of a woman holding a shield and the caption En première ligne dès les premiers signes 'In the first battle line when the first symptoms appear'.

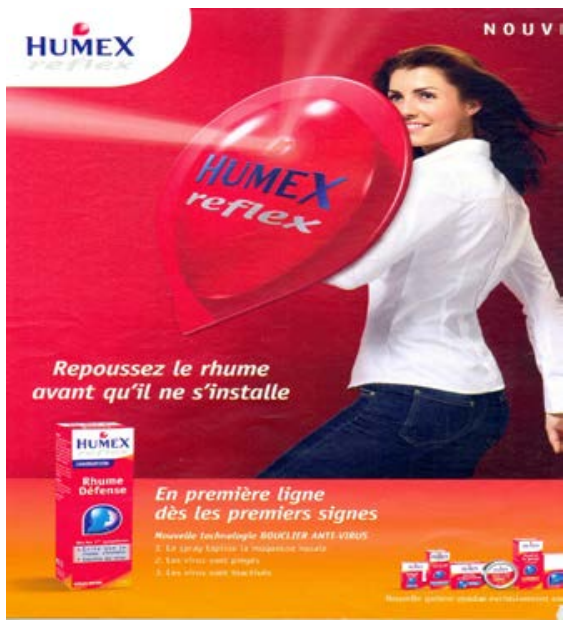

Figure 7: Ad for Humex reflex (Marie-Claire, February 2011). 


\subsection{Analysis of the Cartoons}

Whereas all these advertising metaphors provide a positive evaluation of a product, the visual metaphors instantiated in the cartoons selected conveys a negative evaluation of politicians or political issues in different ways:

(i) through the use of source objects with axiologically negative weight.

(ii) through the use of source objects whose properties reveal an opposition to commonly held positive views about the target object.

(iii) through the creation of a link between two seemingly unrelated domains as a result of a process called symbolizing bisection (Joannis 1988: 59-61). Such link triggers a semantic clash. The bigger the clash, the stronger the evaluation.

(iii) through the use of an intertextuality element with negative properties as the source object.

(iv) through a verbal element. These evaluative techniques are exemplified below.

In the first cartoon (figure 8) politicians are represented as dinosaurs. As Shilperoord \& Maes remark (2009: 227), animals are used in cartoons as prototypical source objects for nations, states or political parties. Dinosaurs are extinct animals. The feature 'ancient' is mapped onto politicians to mean that they are resistant to give up lengthy political careers.

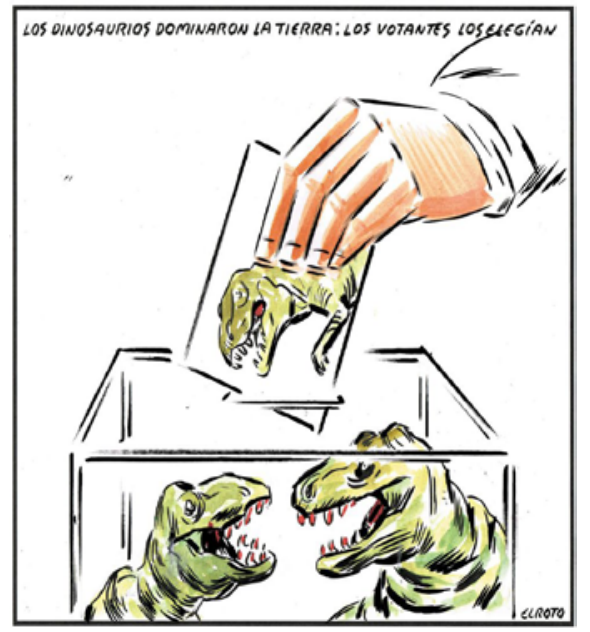

Figure 8: El Roto (El País, 19 December 2015)

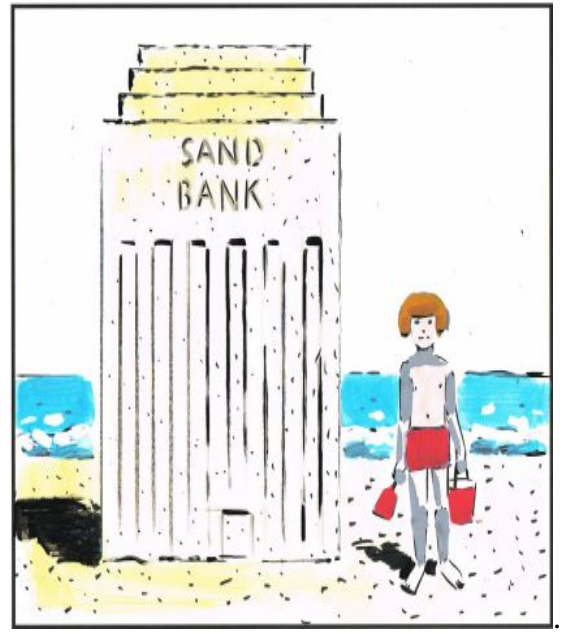

Figure 9: El Roto (El País, 12 July 2015).

The image of the second cartoon (figure 9) encodes the metaphor BANKS ARE SAND CASTLES. The feature 'lightweight' of the source object is translatable into the target object as 'weak'. This negative view of banks stands out against the commonly held view of banks as solid institutions.

The visual metaphor cued by the next cartoon (figure 10) links the domain of politics to such an apparently unrelated domain as variety dancing by showing a Spanish politician dressed as a dancer getting ready for his performance in the 2015 election campaign. This mapping reveals an unfavourable attitude towards Spanish politicians, who seem to believe that their goal is to provide entertainment for large audiences rather than to work for the public welfare. 


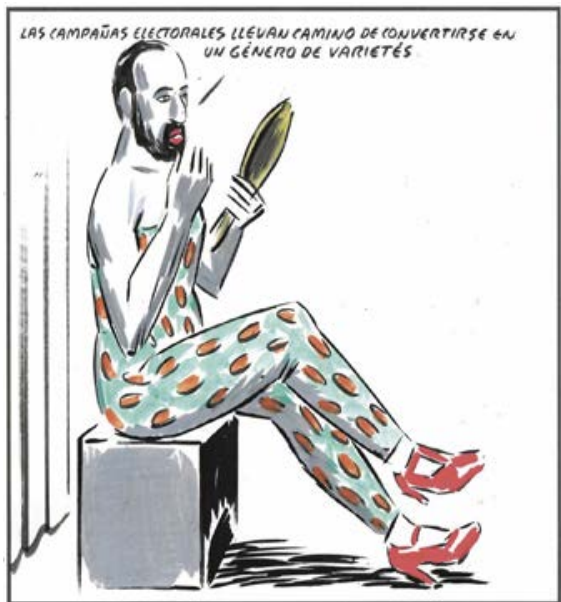

Figure 10: El Roto (El País, 14 December 2015).

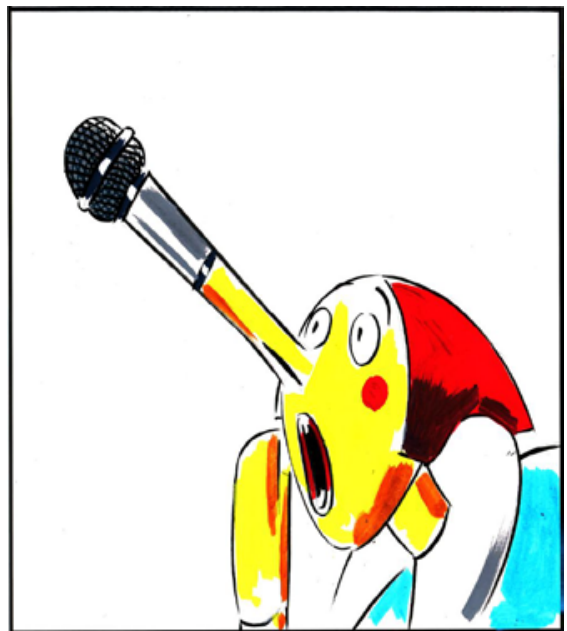

Figure 11: El Roto (El País, 7 June 2015).

The cartoonist's negative evaluation may be cued by an intertextuality element, as shown in figure 11. We see the hybrid image of a goblin with a microphone at the end of his long nose. The long nose, which is reminiscent of Pinocchio, activates the metonymy RESULT FOR ACTION (the bigger nose standing for the action of lying), and the microphone reflects another metonymy, the instrument representing the action of communicating a message. These metonymies provide the basis for the metaphorical conceptualization of journalists as Pinocchio, thus suggesting that the press is not truthful.

In the last cartoon (figure 12) the cartoonist's critical stance is expressed via a verbal element that back the visual metaphor. The black colour and the phrase Mare Mortum contribute to reveal El Roto's strong feelings about a current event, namely the situation of thousands of immigrants who, in their attempt to get to the European coasts, die in the Mediterranean sea, which is renamed as Mare Mortum 'sea of death' instead of Mare Nostrum 'our sea', as the Romans used to call it. The cartoonist indirectly blames European countries for this situation.

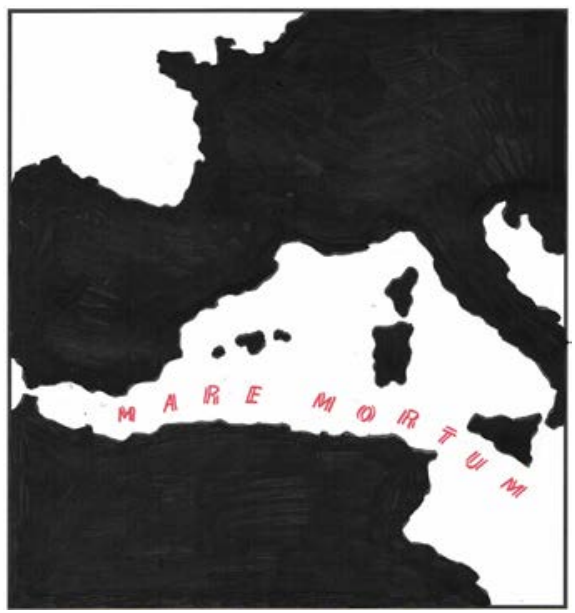

Figure 12: El Roto (El País, 22 April 2015). 


\section{Conclusion}

The present article has attempted to illustrate the role of visual metaphor as an evaluative device in advertising and political cartooning. Advertising metaphor contributes to the primary goal of advertising by promoting the product in two ways, either by enhancing the product features or by presenting it as a necessity for consumers. In contrast, metaphor in political cartooning exemplifies a critical perspective on a political issue or a recent event through (i) the choice of axiologically marked source objects or a source domain that bears no connection with the source domain; (ii) the integration of an intertextuality element; or (iii) the use of a verbal element.

The scope of the paper being limited, further research needs to explore this topic on the basis of a large corpus and in other genres.

\section{References}

Charteris-Black, J. (2005). Politicians and Rhetoric: The Persuasive Power of Metaphor. Basingstoke: Palgrave Macmillan.

El Refaie, E. (2003). Understanding visual metaphor: the example of newspaper cartoons. Visual Communication 2(1): 75-95.

Forceville, C. (2008). Pictorial and multimodal metaphor in commercials in E.F. McQuarrie \& B.J. Phillips (eds.), Go Figure! New Directions in Advertising Rhetoric (pp. 272-310). Armonk, NY: ME Sharpe.

Forceville, C. (2009). Non-verbal and multimodal metaphor in a cognitivist framework: Agendas for research in C. Forceville \& E. Urios-Aparisi (eds.), pp. 19-42.

Forceville, C. \& E. Urios-Aparisi (eds.) (2009). Multimodal metaphor. Berlin/New York: Mouton de Gruyter.

Joannis, H. (1988). O processo da criação publicitário. Portugal: Cetop.

Lakoff, G. (1987). Women, Fire and Dangerous Things: What Categories Reveal about the Mind. Chicago: University of Chicago Press.

Lakoff, G. (2006). The contemporary theory of metaphor in D. Geeraerts (ed.), Cognitive Linguistics: Basic Readings (pp. 186-238). Berlin/New York: Mouton de Gruyter.

Lakoff, G. \& M. Johnson (1980). Metaphors We Live By. Chicago: Chicago University Press.

Lakoff, G. \& M. Johnson (1999). Philosophy in the Flesh. The Embodied Mind and Its Challenge to Western Thought. New York: Basic Books.

Musolff, A. (2004). Metaphor and Political Discourse. Analogic Reasoning in Debates about Europe. New York: Palgrave.

Musolff, A. \& J. Zinken (eds.) (2009). Metaphor and Discourse. New York: Palgrave.

Negro, I. (2013a) Verbo-pictorial metaphor in French advertising. Journal of French Language Studies 24/2: 155-180.

Negro, I. (2013) Visual metaphor and metonymy in French political cartoons. RESLA 26: 365-384.

Negro, I. (2014) Pictorial and verbo-pictorial metaphor in Spanish political cartooning. Círculo de Lingüística Aplicada a la Comunicación 57: 59-84

Negro, I. (2015) Hugo Chávez and the building of his self-image through metaphor. Ibérica 29: 83-104.

Ruiz de Mendoza, F.J. \& L. Pérez (2011). The Contemporary Theory of Metaphor: Myths, Developments and Challenges. Metaphor and Symbol 26: 1-25.

Schilperoord, J. \& A. Maes (2009). Visual metaphoric conceptualization in editorial cartoons in C. Forceville \& E. Urios-Aparisi (eds.), pp. 213-240. 
Silaški, N., \& Durović, T. (2010). Catching inflation by the tail. Animal metaphoric imagery in the conceptualization of INFLATION in English. Ibérica 20: 57-81.

Skorczynska H. \& A. Deignan (2006). Readership and purpose in the choice of economics metaphor. Metaphor and Symbol 21/2: 87-104.

Velasco, M. \& P. Fuertes (2006). Towards a critical cognitive-pragmatic approach to gender metaphors in Advertising English. Journal of Pragmatics 38(11): 1982-2002. 